\title{
Review of English pastoral: An inheritance by James Rebanks
}

\author{
Brian Kerr
}

\author{
Book details \\ Rebanks, J \\ English Pastoral: An Inheritance \\ Penguin Random House, 2020 \\ 286 pages, ISBN: 978-0-241-24572-9
}

Keywords: England, Livestock, Lake District, Nature, Agriculture

The UK has an estimated 30 million sheep, and James Rebanks looks after around a thousand head on his upland farm in the heart of the English Lake District (https://www.nationalsheep.org.uk/uk-sheep-industry/ sheep-in-the-UK). In 2015, Rebanks described life on his family farm in The Shepherds Life: A Tale of the Lake District (Rebanks 2015), which quickly became a nonfiction bestseller and was serialised by the BBC in a Book of the Week, radio broadcast. Since then, the author has become a frequent presence on radio, ranging from dedicated farming topics to general and very popular broadcasts on food, the countryside, and the environment. In the urgent and noisy debate around how we cope with climate change, and the damage to biodiversity in Britain, the media have increasingly sought out authentic voices to balance the often emotional and complicated arguments. An eloquent, well-informed, and practical Lake District shepherd was a welcome addition to any conversation.

It is therefore no surprise that Rebanks has matched his first publication with this second book, which again quickly became a bestseller helped along by a public desperate to take advantage of a blast of fresh Lake District air in the midst of a pandemic. However, this book is different. The author sets out a vision and moves well

Correspondence:wbkerr47@gmail.com

Cranfield University School of Applied Sciences, Cranfield University, Bedford, UK

(c) The Author(s). 2021 Open Access This article is licensed under a Creative Commons Attribution 4.0 International License, which permits use, sharing, adaptation, distribution and reproduction in any medium or format, as long as you give appropriate credit to the original author(s) and the source, provide a link to the Creative Commons licence, and indicate if changes were made. The images or other third party material in this article are included in the article's Creative Commons licence, unless indicated otherwise in a credit line to the material. If material is not included in the article's Creative Commons licence and your intended use is not permitted by statutory regulation or exceeds the permitted use, you will need to obtain permission directly from the copyright holder. To view a copy of this licence, visit http://creativecommons.org/licenses/by/4.0/. 
Keeping sheep on the hill and a family farm solvent depends as much on Rebanks' talent as a writer and his work as a consultant as it does on the Herdwicks and Swaledales. The challenge then becomes how can these livelihoods across upland Britain be maintained in the future. The approach over the past decades has been by governmental support funding for upland farmers. Previously, funding came within a European framework. In the future, the UK government will set up a raft of measures which are designed to transition away from subsidies towards a regime designed to directly relate agricultural funding to the delivery of outcomes considered environmentally beneficial: public funds for public goods.

Added to this wave of uncertainty are market trends away from the consumption of meat, the reality of climate change, and the pressure to allow more public access to the countryside which will complicate the management of upland stock and pastures. Livestock farmers, many of whom are reaching retirement age, also feel threatened by the debate around stocking rates and the argument that lowland flooding can be reduced by tree planting and the need to prevent moorland erosion.

These trends are not confined to Britain. Across Europe, the future impact of agricultural reform and changing patterns of trade is bringing into focus the issue of land abandonment. Estimates of this shrinkage in the areas of agricultural land have been made ranging from 8 to $11 \%$ (https://ec.europa.eu/jrc/en/publication/eur-scientific-andtechnical-research-reports/agricultural-land-abandonmenteu-within-2015). These trends will undoubtably have the greatest impact on livestock grazing farms in the marginal agricultural zones of Europe. Farming systems based on extensive livestock production in harsh conditions are becoming more economically marginal, as governments struggle to justify future subsidy payments. This applies to the Andalusian goat herd and the Lapland reindeer herder, as much as to the Welsh sheep farmer. Often, these areas, including the area described by the author, coincide with locations of high value for nature conservation and tourism where there is a demand for public access. Traffic jams in the Lake District are a frequent holiday problem. Mountain footpaths require millions to maintain and repair.

Seen in these terms, Rebanks is making a plea for a better understanding of a much wider picture, which is about a way of life as much as the landscape or animal husbandry. Removing sheep from these fells in favour of trees, or reducing headage numbers making the business of shepherding unviable, would set in motion a chain of consequences which would alter both the landscapes and the communities.

The layout and structure of the book reflect an urgency to explain the dilemma to a wide audience in a compelling but also straightforward way. The text is aimed squarely at the general reader without pictures or indexes or references. Opening with a short fourpage preface, the author quickly draws the reader into this world of a family farm with a long and deeprooted tradition and then sets the scene for a radical departure from simply carrying on with business as usual and hoping to make do. Three meaty sections follow with the text cleverly broken up into short subsections which are interleafed with direct experiences from the Lake District with the author's reflections and ideas.

The first section entitled Nostalgia sets out how farming in these difficult conditions came to be seen as no longer sustainable. The pages are enlivened, and the points hammered home with keenly observed personal anecdotes which draw the reader in. Nevertheless, the conclusions are sobering:

.... my father and grandfather thought this continuous work was the inevitable price for a good life on the land. Things must be done, because they always had been done. The secret was to settle in your harness and not fight it. Just get on with it. (Page 87).

In the second section entitled Progress, Rebanks draws on his experience of working on an Australian livestock ranch where the individual paddocks were larger than his Lake District home farm. He carefully lays out the dilemma facing marginal European family farms. He had come to understand that both the capital-intensive commercial operations and the present-day small-scale family farming units such as he had inherited from his father were ultimately doomed.

I knew that that if we farmed in more sustainable ways - and no one wanted to pay us to do thatthen we would go bankrupt.

In the final section called Utopia, Rebanks provides an intriguing glimpse of what the future could look like. He brings together real evidence for the changes which are already underway and could be the basis for a sustainable foundation for both the landscape and the communities who provide stewardship for the land. This section invokes the second part of the book title An Inheritance. He clearly sees that the farm and this way of life have been passed to him, and there is a duty, not just to carry on as before, but to improve the holding and secure a viable enterprise which could be handed on. This deeply engrained concept of stewardship runs like a vein of rock through these upland farming families.

I see farmers starting to work together to make this place even better, finding ways to farm around wilder rivers. Miles of hedges are being laid once more, 
drystone walls rebuilt, and old stone barns and field houses restored.

This brings the heart of this book back to people. Many of these improvements are community-inspired, reaching out beyond the traditional core farming families. The vision of a place which brings separate worlds together, replacing an older suspicion between those who work in the place and those who simply live there.

This final section is perhaps the most lyrical of the three, and the description in the last few pages of an encounter at dusk with a barn owl hunting across his pasture land is as fine a piece of nature writing as one could hope for. If only for these passages written with passion, this book is a compulsive read.

At the very end of the text, Rebanks articulates the feelings of many individuals who earn a living from the land in quoting a fellow upland sheep farmer:

Tell them what is happening on the land. Someone has to tell them....

Is the 'Utopia', which is the title of the final section of the book, really possible? Perhaps if more people read this book, the answer could just be yes.

Acknowledgements

Not applicable.

Author's contributions

BK wrote this article with no other contributions. The author has read and approved the final manuscript.

\section{Funding}

The author did not receive any funding for this article.

Availability of data and materials

Not applicable.

\section{Declarations}

Ethics approval and consent to participate

Not applicable.

Consent for publication

Not applicable.

\section{Competing interests}

The author declares that he has no competing interests.

Received: 6 September 2021 Accepted: 7 September 2021

Published online: 24 September 2021

References

Rebanks, J. 2015. English pastoral: An inheritance. London: Allen Lane.

\section{Publisher's Note}

Springer Nature remains neutral with regard to jurisdictional claims in published maps and institutional affiliations.

\section{Submit your manuscript to a SpringerOpen ${ }^{\odot}$ journal and benefit from:}

- Convenient online submission

- Rigorous peer review

- Open access: articles freely available online

- High visibility within the field

- Retaining the copyright to your article 